\title{
Ecos da "Guerra de Canudos" em dois Jornais Protestantes de São Paulo (1896-1897)
}

\section{Resumo}

\author{
Leonildo Silveira Campos*
}

A Guerra de Canudos, em sua fase final (1897), deixou de ser um conflito local, para tornar-se um acontecimento nacional. Várias unidades do Exército foram deslocadas para a região. O conflito deixou aproximadamente vinte mil mortos. A imprensa secular desempenhou um importante papel, mobilizando a opinião pública contra os camponeses liderados por "Antonio Conselheiro". Este artigo tem por objetivo mapear o material publicado em dois jornais protestantes editados na cidade de São Paulo: O Estandarte, dos presbiterianos; e $O$ Expositor Cristão, dos metodistas. A análise a que chegamos foi a seguinte: $\mathrm{A}$ atitude dos dois jornais não foi diferente dos jornais seculares, exceto na atribuição da causa da tragédia à religião dominante - o catolicismo. Porém, o entusiasmo pela República, por parte dos protestantes brasileiros, talvez tenha sido o maior motivo na oposição a Canudos.

Palavras chaves: Canudos, Imprensa Protestante, Antonio Conselheiro, República Velha.

The "Canudos War" Echoes in two Protestant Newspapers of São Paulo (1896-1897)

\section{Abstract}

In its final stage (1897), the Canudos war ceased being a local conflict and became a national tragedy. Several army units were deployed to the conflict area. The death toll was about twenty thousand. The secular press played an important role in mobilizing the public opinion against the Brazilian peasants led by "Antonio Conselheiro". This article aims to map the material published in two different Protestant newspapers of the city of São Paulo: O Estandarte, written by Presbyterians, and O Expositor Cristão, written by Methodists. The conclusion we came to is that none of these newspapers had a different approach to the matter from secular newspapers, except for blaming the dominant religion - the Catholicism - as the cause of the tragedy. However, en-

* Licenciado em Filosofia; Mestre em Administração de Empresas; Doutor em Ciências da Religião (Umesp), 1996; Professor efetivo no Programa de Pós-Graduação em Ciências da Religião da Universidade Presbiteriana Mackenzie. E-mail: leocamps@uol.com.br 
thusiasm for the Republic, by Brazilian Protestants, perhaps was the biggest reason in the opposition to Canudos.

Key words: Canudos, Protestant Press, Antonio Conselheiro, Old Republic.

\section{Resumen}

La Guerra de Canudos en su fase final (1897) ya no fue un conflicto local, pero se convirtió en un evento nacional. Varias unidades del Ejército fueron desplegados en la región. El conflicto dejó cerca de veinte mil muertos. La prensa secular jugó un papel importante en la movilización de la opinión pública en contra de los campesinos brasileños encabezados por Antonio Conselheiro. Este artículo tiene como objetivo plantear el material publicado en dos periódicos protestantes publicados en la ciudad de Sao Paulo: O Estandarte, de los presbiterianos; O Expositor Cristão, de los metodistas. La conclusión del análisis fue el siguiente: Los dos periódicos fueron de ninguna manera diferente de periódicos seculares, excepto en la asignación que la tragedia y la ignorancia habría sido causado por la religión dominante - el catolicismo. Sin embargo, el entusiasmo por la República, por los protestantes en Brasil, tal vez fue la razón más grande en la oposición a Canudos

Palabras claves: Canudos, Protestante Press, Antonio Conselheiro, Antigua República.

\section{Introdução}

Em 1893, numa fazenda abandonada às margens do rio Vaza-Barris, a $400 \mathrm{~km}$ de Salvador, no Estado da Bahia, milhares de peregrinos sem terras começaram a povoar o lugar, reunindo-se sob a liderança do místico e beato Antonio Vicente Mendes Maciel, (1830-1897), mais conhecido como "Antonio Conselheiro". Muitos deles acompanhavam Maciel desde 1874 quando ele e muitos peregrinos se estabeleceram no Arraial do Bom Jesus, vila abandonada em 1893 por causa dos confrontos com a polícia estadual.

Agora, em Canudos ou Belo Monte como o Conselheiro batizou o lugar, ali na "Nova Jerusalém", pobres e pessoas remediadas, que venderam seus bens nas cidades de origens, tentavam recomeçar uma nova vida, menos sofrida e não marcada por secas, violências, fome e miséria. A maior parte dos habitantes da vila de Canudos eram camponeses, ex-escravos e descendentes de indígenas que viam poucas saídas para a crise vivida a não ser o "fanatismo religioso" ou "a violência" no dizer de Rui Facó (1963) em seu mais importante livro, Cangaceiros e fanáticos. ${ }^{1}$

\footnotetext{
1 Essa aproximação entre a religião e violência foi artisticamente retratada em filmes de Glauber Rocha (1939-1981), especialmente em "Deus e o diabo na terra do sol" (1963) e em "O Dragão da maldade contra o santo guerreiro" (1969). Rui Facó, dentro de uma visão marxista, ligou a falta de saída objetiva para os despossuídos da terra, ao latifúndio nordestino e a falta de acesso dos camponeses a terra agriculturável.
} 
Em Canudos, as regras impostas pelo líder organizavam a vida comunitária de maneira rígida. No novo aglomerado ninguém poderia dizer que não tinha exigências morais a cumprir. Os beberrões, as meretrizes, os adúlteros, todos eram escorraçados do povoado. Os autores, inclusive Euclides da Cunha (1963, p. 150, 151), ressaltam a ênfase do Conselheiro na moral católica tradicional, embora usasse para isso uma linguagem típica de uma forma estigmatizante. Cunha escreveu que em Canudos "se firmou logo um regime modelado pela religiosidade do apóstolo extravagante" e a população acatava "às cegas, tudo quanto lhe ensinava aquele; imersa de todo no sonho religioso, vivendo sob a preocupação doentia da outra vida". Assim, continua Cunha, os “jagunços errantes ali armavam pela derradeira vez as tendas, na romaria miraculosa para os céus (...). Ao cair da tarde, a voz do sino apelidava os fiéis para a oração. Faltar às rezas era um crime abominável" (CUNHA, 1963, p. 157).

Essa ligação entre a formação histórica do arraial, a centralidade do movimento ao redor de um místico, e a propensão para o uso da violência tem sido analisada como parte integrante de movimentos de conotação messiânico-milenaristas. Maria Isaura Pereira de Queiroz (1976, p. 225ss) considera Antonio Conselheiro o "mais estudado messias brasileiro" cuja pregação, praticamente, era a condenação da República, vista por ele como "o reinado do Anticristo", o "indício seguro de que o fim do mundo não tardava e contaminara já a própria Igreja Romana, que não escapava também de suas objurgatórias".

Mas, teria sido Canudos um movimento messiânico-milenarista? Teriam aqueles atores consciência de que faziam parte de uma comunidade de inspirados construtores do céu na Terra? Há controvérsias sobre o assunto, porém, há uma certeza; Canudos/Belo Monte foi seguramente um movimento político-religioso que teve como motivação as frustrações, os sonhos e a esperança de milhares de camponeses nordestinos. Esse sonho coletivo terminou no dia 5 de outubro de 1897 em um massacre inominável, no final de uma guerra que provocou mais de vinte mil mortos; a cidadela foi queimada e dinamitada com milhares de cadáveres insepultos; centenas ou milhares de prisioneiros degolados por soldados ávidos de vingança; dezenas e dezenas de crianças ("jaguncinhos") distribuídas entre os vencedores como botim de guerra e levadas para longe do campo de batalha.

Os conflitos que deram origem à guerra começaram como um acontecimento local de rebeldia (1893) contra a cobrança de impostos determinada 
pelo novo regime - republicano - instalado por golpe militar em 1889. Havia, também, a questão da fome e miséria, agravadas pela terrível seca de 1877; o deslocamento de milhares de pessoas para o Norte em busca do milagre da borracha; e a migração para o Sul na esperança de conseguir-se um emprego nas indústrias ou plantações de café.

Canudos foi um fenômeno social, econômico e religioso que se inscreveu dentro de um quadro político muito peculiar. Grandes fazendeiros, com interesses políticos divergentes entre si, mas bem representados em Salvador e na Capital Federal; o clero católico; os comerciantes da região; uniram-se ao redor de uma só bandeira levantada contra um inimigo comum. Para Hermann (1996, p. 81-105) havia conflitos internos entre políticos republicanos e entre os próprios latifundiários baianos que se constituíram no motor da repressão empreendida contra Canudos. Para todos eles era preciso "destruir Canudos para provar que afinal todos lutavam em nome da República".

O líder carismático, conhecido como Antonio Conselheiro, era cearense de nascimento, um ex-comerciante, professor primário, caixeiro viajante, amansador de cavalos, e rábula, tornando-se, a partir do início dos anos 1870 , um pregador peregrino, restaurador de templos, capelas abandonadas e cemitérios. Seus conselhos e sermões eram ouvidos com atenção por centenas de sertanejos que abandonavam tudo para segui-lo.

$\mathrm{O}$ adensamento populacional em Canudos ocorreu com rapidez, pois, três anos após o seu surgimento mais de vinte mil pessoas viviam sob a autoridade do beato Antonio Conselheiro, debaixo da prometida proteção e das bênçãos do Bom Jesus. José Lins do Rego (1973, p. 226, 241) recriou literariamente situações e movimentos como esses para mostrar como os miseráveis da terra afiavam os seus ouvidos para ouvir o chamado de um líder messiânico:

...fazia pena examinar a miséria que estava ali (...). Todos tinham uma fé, uma grande esperança. Os restos de gente do sertão, cegos, feridentos, famintos, tudo esperando o grito que abalasse a formação do mundo (...); o santo embebedara o povo com promessas, com a felicidade de todos, com a igualdade do mundo ....

Estruturalmente, a organização e o funcionamento do novo arraial dependiam de agricultores sem-terra, descendentes de indígenas e de antigos negros escravos, todos sobreviventes das epidemias de fome dos anos anteriores. Porém, essa mistura de gente de várias procedências, que abandonava 
o trabalho nas fazendas da região, foi vista desde o começo com muita desconfiança por fazendeiros, políticos, e autoridades da Igreja Católica.

Os conflitos que resultaram numa guerra civil em Canudos começaram a preocupar seriamente as classes dominantes, em 1893, na vila do Soure, quando os seguidores do Conselheiro quebraram as tábuas com os editais que anunciavam as regras municipais para a cobrança de impostos estabelecida pela República. Foi o primeiro conflito entre os seguidores do Conselheiro e as forças policiais. Daí em diante a espiral de violência somente iria crescer até a destruição do arraial no início de outubro de 1897.

Uma tentativa de mudar o rumo dos acontecimentos foi feita pela Igreja em 1895 por pressão de fazendeiros e do governador. O bispo mandou uma missão composta de padres capuchinhos com objetivo de dispersar milhares de pessoas que se concentravam em Canudos. ${ }^{2}$ Mas, depois de alguns dias, os padres desistiram da missão e abandonaram a região sob pressão dos sertanejos. O relatório por eles preparado foi entregue ao bispo e representava um apelo à intervenção policial e militar. ${ }^{3}$ Nesse contexto aprofundava-se ainda mais o distanciamento entre a religiosidade popular e a hierarquia eclesiástica. O Conselheiro, um leigo católico, passou a ser visto como um líder místico-político independente da Igreja, instituição hegemônica do cristianismo no Brasil e que sempre se considerou sua expressão maior, oficial e legitima. Num contexto de romanização, quando se buscava esvaziar quaisquer tipos de religiosidades leigas, o atrevimento de Maciel era imperdoável.

Por outro lado, Canudos como um fenômeno social, econômico e religioso, inscrevia-se dentro de um quadro político muito peculiar. Grandes fazendeiros com interesses políticos bem representados em Salvador e na Capital Federal uniram-se ao redor de uma só bandeira na luta contra um

2 Essa foi uma das tentativas da Igreja Católica de recuperar o seu secular prestígio de manter a ordem social e cultural no interior do nordeste, segundo Severino Vicente da Silva (1988).

3 Esse relatório foi publicado pelo pesquisador José Calazans (1993-1994, p. 20). Nele, frei João Evangelista de Monte Marciano escreve ao bispo (de acordo com a grafia da época): "Naquella infeliz localidade [Canudos], portanto, não tem império a lei, e as liberdades públicas estão grosseiramente coarctadas. O desagravo da religião, o bem social e a dignidade do poder civil pedem uma providência que restabeleça no povoado dos Canudos o prestígio da lei, as garantias do culto católico e os nossos foros de povo civilizado. Aquela situação deplorável de fanatismo e de anarchia deve cessar para honra do povo brazileiro para o qual é triste e humilhante que, ainda na mais inculta nesga da terra pátria, o sentimento religioso desça a taes aberrações e o partidarismo político desvaire em tão estulta e baixa reação.” Estava aberto o caminho para a repressão policial-militar. 
inimigo comum. A República, depois conhecida como "República Velha", dava os primeiros passos para fortalecer as oligarquias estaduais.

O cenário no interior do nordeste naquelas décadas estava marcado por uma enorme crise econômica e demográfica. O campo se esvaziava devido à migração de mão de obra para o Norte, onde a produção da borracha era estimulada por norte-americanos e, para o Sudeste do País, onde o processo de industrialização exigia crescente mão de obra para as fábricas. Todavia, no Sudeste estava instalada uma crise na produção de café, o principal produto exportador, de onde vinham os recursos para o iniciante processo de industrialização. Entre os nordestinos, retirantes ou não, ainda perduravam os efeitos da seca de 1877, quando, aproximadamente, 100 mil pessoas morreram em conseqüência da fome.

Canudos e sua guerra surgiram num momento em que o Império havia sido derrubado e a República, recém-nascida, tentava sair da ditadura militar em que se metera e a democracia era tão somente um sonho. Por sua vez, as massas se sentiam desligadas de lealdades seculares. Várias revoltas explodiram no Brasil entre 1893 e 1895 e, dez anos depois, na região do Contestado, chegando-se em certos momentos a colocar em perigo a pacificação do país pretendida pelo governo republicano. Daí a necessidade de obter-se apoio popular e levar as elites a um novo pacto político objetivando-se o aprofundamento do processo de reordenação política do país. A Guerra de Canudos parece ter sido encetada exatamente com o objetivo de levar as massas às ruas pela defesa da "pátria ameaçada" e unificar interesses divergentes de políticos e fazendeiros de várias tendências republicanas. Jacqueline Hermann (1996, p. 81-105) registrou que o conflito entre políticos republicanos fez da luta contra Canudos a sua bandeira de unificação; assim "a solução inconciliável desses conflitos precisou destruir Canudos para provar que afinal todos lutavam em nome da República".

O conflito e as hostilidades ganharam velocidade a partir de março de 1897, quando a terceira expedição contra Canudos fracassou com a morte do coronel Moreira Cesar até que, no início de outubro de 1897, a "Tróia de Taipa" foi conquistada. No último ano de luta, por causa de expedições militares frustradas, o conflito, que inicialmente era apenas regional, adquiriu uma dimensão nacional e a sua destruição foi estimulada por uma campanha orquestrada pela imprensa. Foi então que a cidadela de Canudos foi destruída. O Exército brasileiro, depois de algumas expedições frustradas, na quarta expedição, conseguiu eliminar o "reduto de conselheiristas" como era cha- 
mado o arraial. Nessa "pacificação" obtida pelas armas, estima-se que cerca de 20 mil pessoas morreram. Euclides da Cunha (1963, p. 463) escreveu:

Canudos não se rendeu. Exemplo único na História resistiu até o seu esgotamento completo. Expugnado, palmo a palmo (...), caiu no dia cinco, no entardecer, quando caíram os seus últimos defensores, que todos morreram. Eram quatro apenas: um velho, dois homens feitos e uma criança, na frente dos quais rugiam raivosamente cinco mil soldados.

Pois bem, que papel a imprensa laica ou religiosa desempenhou na fase final do movimento de Canudos? E os jornais evangélicos assumiram uma posição semelhante ou diferente da imprensa laica?

\section{A imprensa laica e a Guerra de Canudos}

Alguns jornalistas receberam autorização para cobrir as atividades militares da quarta expedição a Canudos. A luta se tornou tão importante para o país todo que o próprio Ministro da Guerra, general Carlos M. Bittencourt esteve presente no local. Por isso, a cobertura feita pelos jornalistas era submetida à censura militar antes de ser transmitida por telégrafo para seus respectivos jornais.

Na região de Canudos estavam presentes os jornais Gazeta de Notícias (Favila Nunes) e o Jornal do Comércio (Manoel Benício), ambos do Rio de Janeiro ${ }^{4}$ Enviaram também correspondentes os jornais paulistas $O$ Estado de S. Paulo (Euclides da Cunha) e o Jornal do Comércio (Afonso Arinos) ${ }^{5}$. Acompanhava os jornalistas um fotografo oficial levado pelo Exército, cujas fotografias se tornaram expressões iconográficas importantes para registro e análise das últimas semanas de Canudos ${ }^{6}$.

\footnotetext{
4 Manoel Benício foi expulso de Canudos por ter feito críticas ao general Artur Oscar e sua ineficácia na condução da guerra. Benício foi uma exceção, pois, o tom dado pela imprensa em todo o Brasil se baseava numa visão triunfalista da luta do bem contra o mal que havia tomado conta de um horrendo e miserável povoado nos sertões nordestinos. Por isso, houve um silêncio generalizado sobre a degola de prisioneiros desarmados e da violência contra mulheres e crianças.

5 Afonso Arinos, monarquista, denunciou as degolas; e Euclides da Cunha, que se retirou dois dias antes da queda de Canudos por questões de enfermidade, fez uma breve referência a tais crimes em seu livro Os Sertões alguns anos depois.

6 Walnice Nogueira Galvão (1994) fez uma bela análise daquela guerra vista pelo olhar dos jornalistas presentes em Canudos, isto é, dos relatos feitos "no calor da hora".
} 
A imprensa brasileira criou, desde o malogro da expedição de Moreira Cesar, um clima nacional de revanche das cidades contra os "jagunços" e "bandidos do sertão". Canudos "será destruída e não deve ficar pedra sobre pedra" repetia o Presidente da República, o fazendeiro paulista, Prudente de Morais. Os argumentos usados pelos jornais para condenar Canudos à destruição eram como estes: tratava-se de um movimento de pessoas "incultas", "fanatizadas", "não civilizadas", e "desordeiras", que colocava em perigo a República implantada oito anos antes e seu projeto civilizatório.

Os jornais jogaram um importante papel na formação de uma opinião pública anti-Canudos. Isto porque, como bem observou Walnice N. Galvão (1994, p. 15) "o jornal era o mais eficiente veículo de comunicação de massa no Brasil do final do século XIX”. Como tal a imprensa cumpriu a missão que lhe foi reservada: a de influenciar a opinião pública, a convencê-la do "perigo" que Canudos representava para todo o país. Como resultado dessa ênfase jornalística cresceu por todo o Brasil a ideia que Canudos seria um foco de monarquistas e que recebia armas e munição de outros países. Essas acusações, repetidas pelos jornais, calaram profundamente no imaginário coletivo do país ${ }^{7}$. Todos foram seduzidos por eles, inclusive a opinião pública protestante como atestam os dois jornais escolhidos por nós para análise.

\section{Os protestantes e os movimentos contrários à ordem}

O protestantismo quase sempre teve dificuldades com movimentos entusiastas, dependentes de lideranças carismáticas, questionadores da institucionalização das igrejas cristãs e contrários à ordem política vigente. Essa dificuldade ficou bem patente na posição de Lutero diante da Guerra Camponesa de $1525^{\circ}$. Calvino também deixou bem clara a sua posição contra os cristãos "do livre espírito" que, segundo o reformador de Genebra,

Este autor, quando menino nos anos 1950, ouviu de sua avó, nascida em 1889, presbiteriana e filha de cafeicultores do interior de São Paulo, a seguinte história: "Filho, o Brasil vivia tempos difíceis quando a vovó era menina. Tempos de guerra. Havia um homem muito perigoso que ameaçava o País. Um tal de Antonio Conselheiro (...)". Foi essa versão que calou fundo no entendimento das pessoas, até nas mais simples, do Brasil naquela época. O governo republicano à busca de legitimação conseguiu criar, a partir de um bode expiatório, uma unanimidade a seu favor.

8 A posição marxista ficou registrada no texto de Friedrich Engels (1977) sobre as guerras camponesas na Alemanha do século XVI e no livro de Ernst Bloch (1973) sobre Thomas Muntzer. Walter Altman (1992) fez uma excelente reflexão sobre os dilemas de Lutero que se situavam entre a lealdade aos príncipes protestantes e a causa dos camponeses partidários da reforma radical. 
abandonavam as Escrituras Sagradas para crer em revelações divinas e manifestações emocionais dentro do culto cristão. Também há que se acrescentar que o protestantismo, apesar de ter lançado mão, muitas vezes, de armas para defender-se de seus adversários, e de ter nascido de uma ampla revolta contra a ordem política e religiosa, tão logo instalado numa zona de conforto passava ao culto da ordem e à pregação do respeito aos poderosos. Por isso mesmo, alguns dos movimentos que tem causado arrepios nos protestantes mais conservadores ao longo dos séculos são os movimentos religiosos e políticos conhecidos, não sem algumas contestações, como "movimentos messiânico-milenaristas".

Norman Cohn (1981, p. 11), em seu estudo sobre a associação entre mística, messianismo, milenarismo e movimentos revolucionários na Idade Média, afirma que:

As seitas e movimentos milenaristas apresentam sempre a salvação com as seguintes características: coletiva, na medida em que deverá ser gozada pelos fiéis enquanto coletividade; terrena, na medida em que deverá ser realizada neste mundo e não em algum céu de outro mundo; iminente, na medida em que será súbita e para breve; total, na medida em que deverá transformar completamente a vida na terra, de forma que o novo estado de coisas não será apenas um aperfeiçoamento do que existe, mas a própria perfeição; miraculosa, na medida em que deverá ser realizada por, ou com a ajuda de agentes sobrenaturais (os grifos são nossos).

Para Maria Isaura Pereira de Queiroz (1965, p. 5) os movimentos chamados messiânicos ou milenaristas são "agrupamentos organizados que visam substituir uma ordem presente insuportável por um mundo justo e perfeito". Trata-se de uma "recusa da sociedade existente". Ao mesmo tempo, tais movimentos expressam a recusa da passividade resultante da resignação e do conformismo. Esses movimentos de protesto podem expressar-se por meio de uma linguagem nova ou antiga que emerge das profundezas do imaginário coletivo.

François Laplantine (1977, p. 13) captou bem essa reação dos aflitos e marginalizados, que são os primeiros a perceberem uma determinada situação crítica, desta ou daquela sociedade; assim, para esse autor, "a espera messiânica ou milenarista é uma resposta sociológica normal de uma sociedade ameaçada, a partir de dentro e de fora, em seus fundamentos". É nesse contexto que "multidões exploradas e sedentas de absoluto e de justiça social se 
congregam ao redor de grandes profetas ou dos pequenos iluminados" com o objetivo de "transformar seu desespero em esperança". Por tais motivos é que esses movimentos provocam a ira e o temor de todas as camadas sociais que teriam algo a perder com o risco de derrubada da ordem presente. Ao perigo que se avizinha com o despertar dessas massas sofridas, as autoridades lançam mão da repressão. Para elas, as utopias que emergem em tempos de efervescência da desesperança, de formas conscientes ou não, devem ser combatidas a ferro e fogo.

\section{A guerra de Canudos nos jornais protestantes paulistanos (1896-1897)}

A violência da repressão contra o povoado de Canudos e seus habitantes foi um fenômeno que reuniu uma diversidade de atores, além do líder e seus liderados. Fizeram parte desse cenário os grandes latifundiários regionais, os políticos estaduais e federais, o clero católico romano e, a chamado desses, o Exército brasileiro. A imprensa, por sua vez, transformou os primeiros fracassos militares em uma tragédia nacional, especialmente depois da morte do coronel Moreira Cesar no campo de batalha?

Por isso não se pode isentar a imprensa brasileira de sua responsabilidade no acirramento da opinião pública e da disseminação do "clamor nacional" que pedia a destruição total e imediata de Canudos. Ela também teria ajudado a esconder, assim como os religiosos, os verdadeiros interesses que estavam em jogo quando se decidiu pela destruição do "covil de fanáti-

9 A morte do coronel Moreira Cesar em março de 1897 gerou uma comoção nacional e feriu o espírito de corpo do Exército. Como reação popular houve agitação em várias capitais brasileiras e até o empastelamento dos jornais Apóstolo, Liberdade e Gazeta da Tarde, do Rio de Janeiro e do jornal O Comércio de São Paulo. O Estandarte (27/2/97) noticiava que havia chegado à região de Canudos tropas comandadas pelo coronel Moreira Cesar para enfrentar "os fanáticos capitaneados pelo tristemente célebre Antonio Conselheiro, que pelos seus sucessivos e intermináveis crimes tantos males tem causado à paz e a ordem necessária do estado da Bahia e à República”. Para o jornal, Antonio Conselheiro teria conseguido "impor-se como emissário divino à ignorância baixa dos sertanejos daquelas regiões (...) levantar ao seu redor um exército de mais de 10 mil homens que cegamente o obedecem, convictos de que se tombarem no campo do combate que travarem com as forças legaes, em breve ressuscitarão purificados no seio de suas famílias felizes ...". O fracasso da expedição comandada por Moreira Cesar foi notícia na edição de $O$ Estandarte (13 de março de1897) trazendo a notícia da destruição da tipografia de jornais cariocas acusados de serem favoráveis à monarquia. O dono de um deles foi assassinado durante o tumulto no Rio de Janeiro em um ato considerado pelos presbiterianos como "um patriotismo mal entendido" e expresso por atos que "depõem contra nossa civilização". 
cos e bandidos". Na fase final dos combates os principais jornais enviaram jornalistas para cobrir a guerra, fazendo surgir no Brasil, pela primeira vez, a figura do correspondente de guerra. Euclides da Cunha foi enviado pelo jornal O Estado de S. Paulo. Assim, no linguajar dos jornais, inclusive nos artigos de Cunha para o jornal paulistano, o Conselheiro não passava de "um Messias de feira”. Seus artigos foram retrabalhados quando da publicação em 1902 de Os Sertões $(1963: 279)^{10}$.

Os jornais evangélicos, também importante meio de comunicação com alguns milhares de protestantes espalhados então por todo o Brasil, compartilharam do "clamor nacional" que pedia a destruição de Canudos. Um bom exemplo disso pode ser encontrado em $O$ Estandarte ${ }^{11}$ (20 de março de 1897) que apresenta o perfil do comandante dos seguidores do Conselheiro, João Abade, que não passaria de um facínora transformado em "general dos fanáticos", promovido sob a proteção do líder máximo do povoado. Também os homens liderados pelo Abade eram uns "degenerados" que estariam lutando porque tinham a certeza de que, morrendo em combate, iriam conquistar o céu ou ressurgir logo em seguida "para a felicidade do santo e para a glória de seu chefe guerreiro".

Os jornais religiosos, católicos ou protestantes, reproduziam as notícias fornecidas pela imprensa secular que não se cansava de pedir a destruição de Canudos. Quando a destruição se concretizou quase nada foi dito sobre a violência imposta a milhares de pessoas pelos jornais, católicos, protestantes ou seculares ${ }^{12 .}$ Nessas publicações apenas uma palavra de ordem era repetida, semelhante ao slogan que ecoava no Senado de Roma a respeito de Cartago: Delenda est Canudos (Canudos deve ser destruída).

\footnotetext{
10 Uma versão romanceada da Guerra de Canudos ganhou fama na literatura latino-americana. Foi escrita por Mario Vargas Lhosa (2008) e tem por título A guerra do fim do mundo.

11 O Estandarte foi um jornal que surgiu em São Paulo, entre os presbiterianos de tendência nacionalista, em 1893. Dez anos depois, com a cisão ocorrida no meio presbiteriano e o surgimento da Igreja Presbiteriana Independente (1903), esse jornal tornou-se uma espécie de órgão oficial da nova denominação protestante.

12 Uma honrosa exceção foi o manifesto dos estudantes da Bahia (acadêmicos de direito, medicina e engenharia), recuperado por José Calazans (1993, p. 6ss) no qual, quando terminada a guerra de Canudos, eles se levantaram para condenar as mortes por degola afirmando que "aquelas mortes pela jugulação foram, pois, uma desumanidade sobreposta à flagrante violação da justiça (...). Ser herói não é simplesmente vencer, mas vencer com justiça, respeitando o direito".
} 
Analisamos, neste curto espaço, a reação protestante em dois jornais: $O$ Expositor Cristão ${ }^{13}$ e $O$ Estandarte, ambos publicados em São Paulo e fundados nas duas últimas décadas do século XIX. No jornal metodista, O Expositor Cristão, missionários americanos de vocação republicana estavam à frente dele. Eles mantinham estreitas ligações com fazendeiros de Piracicaba, entre eles os dois irmãos Moraes Barros. Um deles, Prudente de Morais, tornou-se o primeiro Presidente civil. Ele era Presidente da República nos tempos de Canudos. O Expositor Cristão (16 de outubro de 1897) assim saudou o fim da guerra: "Tomada de Canudos. Gloriosa notícia! Sentimos uma verdadeira alegria; nosso coração se expandiu de um gozo indizível e sentiu-se muitíssimo aliviado, quando soava a voz: Canudos caiu!" Já antes da guerra de Canudos o jornal apresentava as congratulações metodistas com o novo presidente eleito, Prudente José de Moraes Barros, apoiador do metodismo e do Colégio Piracicabano: "saudamos alegremente o nosso governo".

Já o jornal dos presbiterianos de São Paulo, O Estandarte, pouco publicou sobre o fim do conflito. Mas, já na edição de 27 de fevereiro de 1897, havia uma coluna sob o título "fanatismo" que se referia à terceira expedição enviada a Canudos, a do coronel Moreira Cesar:

Chegadas ao ponto de seu destino, as forças comandadas pelo coronel Moreira Cesar, a esta hora já deve ter entrado em operação contra os fanáticos capitaneados pelo tristemente célebre Antonio Conselheiro, que pelos seus sucessivos e intermináveis crimes tantos males tem causado à paz e à ordem necessária ao estado da Bahia e à República.

$\mathrm{Na}$ segunda edição do mês de março (O Estandarte, 13 de março de 1897) há o registro da derrota da terceira expedição:

Deu-se o combate entre as forças comandadas pelo coronel Moreira Cesar e a orda de fanáticos a soldo dos conselheiros do regimen decahido e capitaneados pelo beato Antonio Conselheiro. Foram mortos o referido commandante das forças legaes e diversos officiais, do que resultou completo desbaratamento da expedição. Como era de prever a divulgação de uma tal notícia agitou fortemente a alma popular (mantida a grafia da época).

O Estandarte (13 de março de 1897), no final da coluna, registrou as reações populares à derrota da expedição comandada por Moreira Cesar,

13 O Expositor Cristão foi fundado em 1886 pelos missionários metodistas e tornou-se, até os dias de hoje, o jornal oficial da Igreja Metodista do Brasil. 
especialmente no Rio de Janeiro e em São Paulo, que deixou vários jornais destruídos, isto é, jornais que tinham fama de serem adeptos do antigo regime monárquico. Porém, os presbiterianos expressavam uma falsa neutralidade política: "A nossa missão [do jornal] é toda de paz e de concórdia. Registrando fatos tão lamentáveis só têm a deplorar que homens que podiam prestar tão bons serviços à pátria (...) viriam a provocar factos taes e que tanto deppõem contra nossa civilização" (mantida a grafia da época).

Nas edições dos cinco meses seguintes nada mais foi encontrado até que, em $O$ Estandarte de11 de setembro de1897 lemos: "De coração nos associamos às festas que em todo o país estão sendo feitas pela tomada de Canudos e, consequentemente, pelo restabelecimento da paz em nossa pátria”. Nessa mesma edição houve a reprodução de uma carta enviada por um soldado diretamente da frente de combate. Esse soldado talvez fosse presbiteriano, pois foi apresentado pelo jornal como "nosso irmão de fé". Esse militar fazia parte do $35^{\circ}$ Batalhão de Infantaria. Participou de uma batalha quando a sua unidade foi atacada pelos conselheiristas, contra os quais reagiu à baioneta. Depois de sete horas de luta, conta ele, eram muitos os mortos em especial do lado do que ele chamava de "fanáticos seguidores do Conselheiro". No final da descrição da batalha ele conclui: "depois de sete horas de fogo conseguimos colocar em fuga os bandidos (...). Graças a Deus passei incólume". Na carta ele relata ter saído de Teresina em 15 de março de 1897 a fim de "bater os fanáticos de Antonio Conselheiro no miserável antro de Canudos onde estão encerrados os bandidos". Nessa carta o missivista se refere ao "fanatismo do povo de Antonio Conselheiro, bandido chefe dessa horda". Na conclusão da carta ele escreve, ainda segundo o jornal dos presbiterianos, que os monarquistas "nossos eternos inimigos" é que estão por detrás desses fanáticos.

Os jornais evangélicos, assim como os seculares, não trouxeram nenhuma notícia ou quaisquer palavras sobre as mortes por degola aplicada aos prisioneiros, que foram eliminados após se entregarem sob a palavra do comandante militar de que suas vidas seriam preservadas. Nessa tragédia final, que não foi omitida nem por Euclides da Cunha (1963, p. 428ss), predominou a morte imposta pela decapitação à faca ou à baioneta com a separação da cabeça do corpo ou a exposição das vísceras do infeliz que eram arrancadas por arma branca. $\mathrm{O}$ autor de $\mathrm{Os}$ sertões não usou meias palavras para referir-se a "um destripamento rápido" dos aprisionados. Isto porque, em Canudos, segundo ele, "a repressão tinha dois pólos - o incêndio e a faca". Portanto, 
não se tratava mais de uma guerra convencional contra um inimigo, pois, o que houve, no final da guerra, foi uma demonstração de barbárie por parte dos militares ávidos de vingança. "Aquilo não era uma campanha era uma charqueada" arrematou Cunha (1963, p. 432) ${ }^{14}$.

Nos meios católicos não se rezaram missa alguma pela alma dos seguidores do Conselheiro ou do próprio Antonio Maciel ${ }^{15}$. Houve, no entanto, missas quando da ida de soldados para o front e, depois, em favor da alma dos que morreram em ação ou na volta dos "vencedores"16. Estas últimas cerimônias não passaram despercebidas de $O$ Estandarte (6 de novembro de 1897) que censurou o uso de edifício público e a participação do próprio governador de São Paulo, Campos Salles (futuro presidente da República), numa missa campal "em homenagem à memória dos heróicos soldados do batalhão paulista, mortos no sertão baiano, em luta com o fanatismo impenitente". O Estandarte (6 de novembro de 1897) reproduzia a descrição feita pelo jornal secular, o Correio Paulistano, do cenário montado em frente da Escola Normal, na Praça da República - um altar católico. O ponto alto da missa, conforme os jornais, ocorreu quando ao som de toque de clarim o celebrante levantou a hóstia consagrada e a "grande massa de soldados contritamente ajoelhou-se".

Conforme o olhar do jornal O Estandarte o fato "escandaloso" não estava nas notícias dos milhares de mortos, a maioria do lado dos "jagunços", mas na quebra da regra constitucional que, num Estado laico, deveria ser mantida: a separação entre a Igreja e o Estado. O lamento dos presbiterianos

14 Sessenta dias antes da queda de Canudos, o jornal metodista (Expositor Cristão, 10 de julho de 1897, p.2), reproduzindo notícias de O Paíz, calculava em dois mil o número de mortos até então. A estimativa é de que morreram por volta de 20 a 30 mil brasileiros nessa guerra infeliz. Mas o número exato desses mortos possivelmente nunca será conhecido.

15 Já quanto aos soldados mortos em combate havia uma preocupação religiosa em garantirlhes a salvação da alma. Às vezes havia exageros, tal como o ocorrido com a notícia falsa da morte de um tenente por nome Mario Barbosa. Várias missas foram rezadas em intenção de sua alma até que o seu comandante mandou telegramas informando: "Ele está vivo, parem com isso". No interior de Minas Gerais um fazendeiro tentou sem sucesso mandar celebrar missa pela alma do Conselheiro. Chegou a montar um simulacro de velório no interior da Igreja, mas seu intento foi frustrado pelos moradores da região (Expositor Cristão, 28 de agosto de 1897).

16 O jornal Gazeta de Notícias (3 de abril de 1897), notícia reproduzida por Walnice Galvão (1994), registrou o seguinte convite para missa: "O partido republicano autonomista manda celebrar, às 10 horas de hoje, na matriz desta cidade, uma missa com 'libera-me', pelo repouso eterno dos heróicos defensores da Republica, vítima dos assalariados monarquista; para esse ato convida todos os que sabem prezar o amor da Pátria" 
é que a fachada de uma escola pública havia se transformado em "um altar da idolatria romanista". Nada quanto ao cenário árido do nordeste tingido de vermelho do sangue expelido por milhares de gargantas cortadas por soldados, embriagados pela vitória, em fim de festa.

No episódio de Canudos, a Igreja romanizada uniu-se aos positivistas, a protestantes republicanos, que derrubaram o Império e promoveram a separação entre Estado e Igreja, para reprimir um católico leigo talvez mais fiel do que os padres que o acusavam ${ }^{17}$. Agora os inimigos católicos, maçons e positivistas formavam uma só frente contra a "desordem" produzida por uma prática religiosa e por um líder carismático, que emergia do catolicismo popular praticado pelas massas que seguiam um beato e que, por sua vez, representava a velha tradição do catolicismo sertanejo. Isto significa que quando o risco de "desordem" surge, ainda que provocado por um messias ou um profeta qualquer, não há outra saída para os dominadores a não ser a estratégia de implantar-se um período de repressão exemplar.

A repressão foi feita em nome da preservação da jovem República, que ainda não tinha completado seus oito anos de idade e já estava em perigo. Por isso caberia à Igreja, também vítima parcial da República, ajudar no processo de "pacificação" do sertão nordestino. O processo civilizatório imaginado pelos republicanos teria que ser imposto sobre a "irracionalidade" dos jagunços fanáticos, ainda que fosse à custa de baionetas caladas. Nesse caso, tal como em outros movimentos de contestação político-religiosos, a morte e a violência seriam o meio de recuperação da "ordem" e do "progresso", destinando-se à "cultura brasileira" apenas a função de "apagamento de rastros" no dizer de Francisco Foot Hardman et alii. (1998).

\section{Considerações finais}

A história de Canudos tem sido recontada e a sua memória é constantemente reinterpretada. Sobre isso há uma extensa bibliografia. Por exemplo, Paulo Emílio Matos Martins (2001), em A reinvenção do sertão ressaltou a dimensão administrativa e organizacional de Canudos; Edmundo Moniz (1978) fez uma releitura ideológica das lutas que envolviam Antonio Maciel e sua gente; Pedro Lima Vasconcellos (2010) e Alexandre Otten (1990) analisaram a dimensão teológica e religiosa. Um setor da Igreja, envolvido com a Teologia

\footnotetext{
17 Quando da Guerra de Canudos o processo de romanização da Igreja Católica, iniciada nos tempos do Concílio Vaticano I, estava quase atingindo os seus objetivos, segundo o estudo de Pedro Oliveira (1985).
} 
da Libertação, a partir dos anos 1980, retomou a idéia plantada por Moniz (1978) da comunidade messiânica movida pelo ideal da igualdade e da justiça. Assim a imagem e a luta do Conselheiro, cuja primeira reconstrução foi a de Euclides da Cunha, vai sendo reelaborada de acordo com ideologias e diversos pontos de vista em evolução ${ }^{18}$ Isto não quer dizer que a versão dos fatos divulgada pelos dois jornais evangélicos aqui citados não tenham sido também altamente ideologizadas.

Uma visão religiosa interessante foi apresentada por Oswaldo Borges Profeta (1990) em um romance histórico que expressa uma versão protestante do massacre de Canudos ${ }^{19}$. Nesse livro, Canudos - Libelo de um massacre, Antonio Conselheiro aparece como um homem íntegro, um verdadeiro profeta, que inclusive carregava consigo sempre um exemplar da Bíblia no qual baseava os seus sermões. Por isso, Borges Profeta considerou Antonio Conselheiro um "quase protestante", que por meio da leitura da Bíblia foi se afastando da ortodoxia católica. Para ele, uma análise dos sermões e conselhos dados à luz das Sagradas Escrituras provam que o Conselheiro era um indivíduo "ilustrado, consciente e fervoroso na doutrina evangélica" (Profeta, 1990, p. 270ss). O puritanismo e o rigor do comportamento do Conselheiro talvez tenham estimulado as conclusões desse autor. Canudos para ele é conseqüência da "intolerância político-religiosa", da "perseguição impiedosa e intransigente da Igreja e, posteriormente, da República".

Apoiado em Ataliba Nogueira, Profeta supõe que, na fase final de sua carreira, Antonio Maciel teria encontrado apoio espiritual na leitura e aplicação da Bíblia à sua vida diária. Os seus sermões escritos, publicados somente nos anos 1960, atestariam a existência de uma religiosidade quase protestante. Para Nogueira, como para outros articulistas de jornais evangélicos, a tragédia de Canudos só foi possível por causa da Igreja Católica que teria gerado, segundo a ótica anticatólica, uma cultura marcada pela ignorância

\footnotetext{
18 Um documentário dirigido por Antonio Olavo (1993) intitulado Paixão e guerra no sertão de Canudos mostra depoimentos e rituais próprios dos grupos religiosos da Bahia que recontam a história do Conselheiro à luz da dicotomia oprimidos x opressores, ressaltando-se a imagem do Cristo libertador.

19 Oswaldo Borges Profeta, nascido em 1924 e ainda vivo em São Paulo, é filho de um antropólogo e missionário batista. No início dos anos 1950 casou-se com a filha de um ministro presbiteriano. Por 25 anos foi aviador e, em 1955, durante a campanha presidencial de Juscelino Kubitschek, foi o seu piloto. Nessa ocasião tomou conhecimento da tragédia de Canudos, o que seria objeto de seus estudos num mestrado em Direito na Universidade Presbiteriana Mackenzie.
} 
e superstição. Já o protestantismo teria vindo com as luzes da civilização e do Evangelho para redimir o Brasil. É claro que os episódios de "fanatismo" religioso, também de inspirações messiânico-milenaristas, como os casos de Malacacheta (1955), estudado por Renato Queiroz (2015, p. 153) e o episódio dos Mucker (1874) por Janaína Amado (1997) não cabem dentro de tal paradigma, pois, foram eventos ocorridos entre protestantes, adventistas da promessa, no primeiro caso, e o segundo entre luteranos ${ }^{20 .}$

No entanto, como mostra o frei Francisco Benjamin de Souza Netto (1995), na revista da Associação dos Seminários Teológicos Evangélicos (ASTE), o Conselheiro que emerge dos sermões escritos e editados por Ataliba Nogueira (1974) não é um messias, nem um profeta inovador. A sua mensagem e teologia são tipicamente conservadoras e defensoras de uma ordem que teria sido estabelecida por Deus no início dos tempos. E que, o tempo presente vivido por ele e por seus seguidores, seria semelhante ao tempo dos sofrimentos de Cristo. Mudanças estavam ocorrendo e um período de atribulações marcaria a passagem dos eleitos para a vida eterna no paraíso.

Hoje, 120 anos se passaram da tragédia de Canudos. À luz dos conhecimentos atuais em Sociologia, História ou em Ciências da Religião, é possível perceber-se que o movimento de Canudos foi uma reação de camponeses pobres que se sentiram desorientados quando do avanço da modernidade capitalista no interior do Brasil. Ao se sentiram desconectados da tradição e dos esquemas tradicionais de arranjos sócio-culturais eles se entregaram a uma experiência de recomposição de suas crenças, hábitos e costumes, passando a vivenciar uma proposta transformada em visão de mundo pelo peregrino Antonio Conselheiro.

O impacto da modernidade chegou até eles na figura da República que teria esmagado o Império, reorganizando, politicamente, a sociedade a partir de novos valores, impondo outras formas de racionalidade no governo, na cobrança de impostos, e até em termos de pesos e medidas; do protestantismo como um perigo religioso, que aliado aos maçons, ao positivismo e a outras forças culturais modernizantes estaria afetando diretamente o sentimento religioso do povo católico. Essas forças munidas de outras lógicas, na expressão de Christian Parker (1996), colocavam em perigo a visão de mundo tradicional camponesa que precisava ser mantida, ainda que fosse de forma simbólica. Os protestantes, por sua vez, reconheciam-se como portadores de uma mensagem liberal, anticatólica e, sobretudo republicana.

20 O episódio de Malacacheta foi estudado por Renato Queiroz (2015: 153) e dos Mucker, por Janaína Amado (1977). 
Canudos foi uma manifestação de resistência a tantas mudanças que aconteciam ao redor de uma população sertaneja pobre, nos moldes propostos para outros movimentos, conforme a coletânea organizada por Márcia Motta e Paulo Zarth (2008), Formas de resistência camponesa: visibilidade e diversidade de conflitos ao longo da história. Assim, o caminho seria a reafirmação do tradicionalismo, a volta ao que eles consideravam ser mais sacro porque mais antigo, a um catolicismo mais "rústico" e a uma forma de governo anterior e idealizada, o império, que teria sido "estabelecido" por Deus.

Talvez a expressão mais autêntica do sentimento republicanista dos protestantes tenha sido registrado pelo Expositor Cristão, jornal metodista quando, do fim da guerra, o responsável pelo jornal reafirmava a sua satisfação pela queda de Canudos, como foi citado algumas páginas atrás. O jornal O Estandarte (9 de outubro de 1897) dos presbiterianos foi mais comedido e registrou: "Do coração nos associamos às festas que em todo o Paíz estão sendo feitas pela tomada de Canudos e, consequentemente, pelo restabelecimento da paz em nossa pátria”. Discordava, porém, das maneiras católicas de comemorar-se por meio de missas.

A reação dos protestantes à Guerra de Canudos se deve também à apreciação deles pelo republicanismo e pela forma norte-americana de democracia. Soma-se a isso a enorme tendência que os protestantes sempre tiveram em apoiar todas as tentativas de manutenção da ordem política, reafirmada, às vezes, pelo cruzar de braços diante das atividades ligadas a organização política da sociedade, ou pelo apoio ostensivo a ditaduras militares. Para eles, o governo sempre deve ser obedecido, havendo limites para a desobediência civil ainda que esteja à frente do governo um déspota. Canudos representava, portanto, o oposto do modelo presbiteriano e metodista de governo. Antonio Conselheiro encarnou para eles a figura do "líder tenebroso", chefiando um "bando de fanáticos".

Pesou também na balança a intimidade que especialmente os metodistas tiveram com o Presidente da República do período da Guerra de Canudos, Prudente de Moraes. Até então os metodistas e presbiterianos estavam encantados com a República e muito contentes pela separação entre Igreja e Estado. Todavia, as décadas seguintes da República Velha iriam provocar um desencantamento que não foi, absolutamente, por causa das matanças promovidas durante a repressão de alguns movimentos político-religiosos como Canudos, Contestado e outros. A decepção com a República viria, posteriormente, com manifestações do "Brasil profundo", do "País real" onde as leis 
que garantiam a liberdade de culto não eram colocadas em prática. No final da República Velha (revolução de 1930) os dois jornais voltariam a ressaltar os ideais republicanos de 1889, os quais, agora, estariam em perigo diante de uma tentativa da Igreja Católica de retomar o lugar perdido quando do Golpe militar, quarenta e um anos antes.

Os presbiterianos ou calvinistas nunca deixaram de reagir a episódios ocorridos na história provocados por lideranças carismáticas ou por abruptas rupturas da ordem social. Talvez não seja uma mera coincidência que Roger Bastide (2005), sociólogo de tradição religiosa calvinista, considerou a religião como resultante de uma "domesticação do sagrado" que, segundo ele, se apresenta, inicialmente, de forma bruta e selvagem nas religiões de transe e de êxtase.

O milenarismo, para Bastide (2005, p. 177) deve ser visto como uma "estratégia de busca de uma nova identidade e dignidade" por parte de um grupo social que as perderam. Assim, para Bastide (2005, p. 181) "o messianismo aparece toda vez que ocorrem, na sociedade ou na cultura, mudanças que venham questionar os antigos valores e os equilíbrios reconhecidos de status, quer essas mudanças, aliás, se devam a causas externas, como a colonização, quer as causas internas ...". Portanto, as afirmações de Bastide são muito apropriadas para se examinar-se o movimento de Canudos, não somente em virtude da visão de um sociólogo do porte dele, mas, também, da visão de alguém que sempre se colocou em um estado de tensão entre a tradição calvinista-francesa e os novos valores que adquiriu em sua experiência no estudo de religiões afro-brasileiras.

Essa posição de Bastide aparece também no prefácio à primeira edição do livro de Maria Isaura Pereira de Queiroz (1976), na qual registra que a autora descobriu que há

...por detrás do catolicismo rústico ou do sebastianismo, isto é, das utopias ou dos sonhos coletivos, uma 'sociedade' presente, reagindo a certos estímulos internos ou externos; e também a tendência inconsciente de um grupo de homens, num lugar dado, para reestruturar, para reequilibrar, para anular as tensões insuportáveis, abalando os quadros habituais da vida.

Também, Glauber Rocha (1939-1981), filho de mãe presbiteriana e educado em colégio presbiteriano na Bahia, levou para o cinema a tensão entre religiosidade popular nordestina e a violência do cangaceirismo, dos jagunços e fazendeiros. No filme Deus e o diabo na terra do sol (1963) o sertanejo Manoel, 
depois de conflitos com latifundiários com quem tinha negócios cuidando de gado, junta-se a um grupo religioso liderado por um santo (Sebastião) que luta contra os proprietários de terra e prega o paraíso situado na vida após a morte. No filme $O$ dragão da maldade contra o santo guerreiro (1969), um matador de aluguel é contratado pelos latifundiários para eliminar o santo e seus seguidores. Porém, no caso de Bastide e de Glauber Rocha, a simpatia deles pendeu para o lado das vítimas do colonialismo e da injusta política de distribuição de terras no país.

Por tudo isso, concluímos que os protestantes brasileiros de tradição presbiteriana ou metodista, conforme os seus jornais, posicionaram-se contra Antonio Conselheiro por vários motivos: por ,motivo do anticatolicismo deles, embora o Conselheiro fosse praticante de um catolicismo rústico demais para uma valorização de sua rebeldia contra o clero católico-romano; depois em vista do anti-republicanismo do Conselheiro, pois, para os protestantes brasileiros, a introdução da República era vista como uma bênção divina, trazendo liberdade de crença ao separar a Igreja do Estado; houve ainda, na rebelião de Canudos contra a ordem social e política, um risco para a República recém implantada, um regime tão valorizado pelos missionários protestantes norte-americanos que atuavam no Brasil naquele momento.

Não se pode esquecer que após o golpe militar de 1889, já na quinzena seguinte, o jornal metodista, Expositor Cristão (1 ${ }^{\circ}$ dezembro de 1889), tendo à frente de sua redação o pastor norte-americano, James F. Kennedy, assim registrou a exaltação dos metodistas pelo acontecido:

7 de setembro assinala a independência da nação brasileira; 13 de maio marca a época gloriosa da emancipação dos escravos do Brasil; porém, 15 de novembro, até hoje, é o dia mais glorioso na história desta grande nação. Pois este traz mais do que a liberdade dos nossos corpos. Com ele raiou a liberdade de consciência, a liberdade religiosa (...). O povo brasileiro é um grande povo; porém por ter sido a sua consciência escravizada e cauterizada por séculos pelos grilhões do Romanismo e jesuitismo, ele não tem podido desenvolver-se (...). 15 de novembro é um dia muito auspicioso. Pois, para todos os cidadãos, ele prognostica igualdade, equidade e justiça....

Em Piracicaba, a oligarquia cafeeira favorável à República acolheu bem os missionários metodistas e os incentivou na criação naquela cidade de um Colégio Evangélico. Ali pontificavam Caetano de Campos, Rangel Pestana, e os irmãos Manoel e Prudente de Moraes. Este último era Presidente da 
República quando ocorreu a repressão sangrenta do movimento político-religioso de Canudos. Marta Watts (Watts, in Mesquita, 2001, p. 90), missionária metodista, fundadora do Colégio Piracicabano, que posteriormente daria origem a Universidade Metodista de Piracicaba, registrou em uma de suas cartas enviadas aos Estados Unidos:

O Brasil está indo para frente, e devemos seguir com ele, carregando a religião do Evangelho (...). Eu não escrevi sobre a República, mas digo que a vida tem tido um sentido maior no Brasil desde 15 de novembro de 1889 (...); todos os homens são livres para louvar a Deus de acordo com o que dita suas próprias consciências neste Brasil beato e dirigido por padres.

O apoio dos metodistas ao Golpe de 1889 produziu resultados mais rápidos do que o esperado. A solicitação de reconhecimento jurídico da Missão Metodista no Brasil, engavetada durante muito tempo pelas autoridades imperiais, imediatamente foi assinada e sancionada nestes termos:

O Marechal Manoel Deodoro da Fonseca, chefe do Governo Provisório constituído pelo exército e armada, em nome da nação, atendendo ao que requereram os membros da Associação da Igreja Metodista Episcopal do Sul, no Brasil, resolve aprovar, para os efeitos civis, os Estatutos da mesma associação (Decreto Lei de 1 de dezembro de 1889).

Fica claro, portanto, que a identificação de presbiterianos e metodistas com a República, por si só, explicaria a repulsa à luta empreendida pelos moradores de Canudos, liderados por Antonio Conselheiro, pois, aqueles eram apresentados como "monarquistas" e "inimigos da República”. Porém, os protestantes brasileiros queriam mais do que um Estado republicano, talvez quisessem um Estado anticatólico. Daí uma crescente desilusão que começaria a campear entre eles já nos primeiros anos do século XX com respeito ao futuro da República. Os mesmos jornais dos anos 1930 assumiriam outros discursos e retóricas. 


\section{Referências}

ALTMANN, Walter. Lutero e a libertação. São Paulo: Atica, 1992.

AMADO, Janaína. Conflito social no Brasil: A revolta dos "Mucker", Rio Grande do Sul, 1868-1898. São Paulo: Símbolo, 1977.

BASTIDE, Roger. O sagrado selvagem e outros ensaios. São Paulo: Companhia das Letras, 2005.

BLOCH, Ernst. Thomas Müntzer - Teólogo da revolução. Rio de Janeiro: Tempo Brasileiro, 1973

CALAZANS, José. A Faculdade de Direito da Bahia e a Guerra de Canudos. Revista USP, n. 20, p. 8-11, outubro de 1993-abril de 1994.

COHN, Norman. Na senda do milênio: Milenaristas revolucionários e anarquistas místicos na Idade Média. Lisboa: Editorial Presença, 1981.

CUNHA, Euclides da. Os sertões - Campanha de Canudos. 27. ed. Brasília: Editora da UnB, 1963.

ENGELS, Fredrich. As guerras camponesas na Alemanha. São Paulo: Grijalbo, 1977.

ESTANDARTE, O. Jornal presbiteriano de São Paulo. Edições de 27 de fevereiro de 1897; 13 de março de 1897; 11 de setembro de 1897; 9 de outubro de 1897; 6 de novembro de 1897.

EXPOSITOR CRISTÃO. Jornal metodista de São Paulo. Edições 10 de julho de 1897; 28 de agosto de 1897; 16 de outubro de 1897.

FACÓ, Rui. Cangaceiros e fanáticos. Rio de Janeiro: Civilização Brasileira, 1963.

GALVÃO, Walnice Nogueira. (Org.). No calor da hora: A guerra de Canudos nos jornais, $4^{a}$ expedição. 3. ed. São Paulo: Ática, 1994.

HARDMAN, Francisco Foot. (Org.) Morte e progresso: Cultura brasileira como apagamento de rastros. São Paulo: Editora UNESP, 1998.

HERMANN, Jacqueline. Canudos destruído em nome da República - uma reflexão sobre as causas políticas do massacre de 1897. Revista Tempo, v.2, n.3, p. 81-105,1996.

LAPLANTINE, François. Mesianismo, posesion y utopia: Las tres voces de la imaginación colectiva. Barcelona: Gedisa, 1977.

LHOSA, Mario Vargas. A guerra do fim do mundo. Rio de Janeiro: Objetiva, 2008.

MARTINS, Paulo Emilio Matos. A reinvenção do sertão: A estratégia organizacional de Canudos. Rio de Janeiro: FGV, 2001.

MONIZ, Edmundo. A guerra social de Canudos. Rio de Janeiro: Civilização Brasileira, 1978.

MOTTA, Márcia; ZARTH, Paulo. (Org.). Formas de resistência camponesa: visibilidade e diversidade de conflitos ao longo da história. São Paulo: Editora UNESP, 2008. 
NOGUEIRA, Ataliba. Antonio Conselheiro e Canudos. São Paulo: Companhia Editora Nacional, 1974.

OLAVO, Antonio (direção e roteiro). Paixão e guerra no sertão de Canudos - Filme documentário em vídeo. Salvador, Bahia: 1993 (Filme premiado no X Rio Cine Festival, 1994).

OLIVEIRA, Pedro A. R. de. Religião e dominação de classe - Gênese, estrutura e função do catolicismo romanizado no Brasil. Petrópolis: Vozes, 1985.

OTTEN, Alexandre. "Só Deus é grande”. A mensagem religiosa de Antonio Conselheiro. São Paulo: Loyola, 1993.

PARKER, Cristián. Religião popular e modernização capitalista: outra lógica na América Latina. Petrópolis: Vozes, 1996

PROFETA, Oswaldo. Canudos - Libelo de um massacre. Uma visão religiosa da Guerra de Canudos. São Paulo: Casa Editora Presbiteriana, 1990.

QUEIROZ, Maria Isaura Pereira de. O messianismo no Brasil e no mundo. 2. ed. São Paulo: Dominus-Edusp, 1965.

QUEIROZ, Renato Silva. O demônio e o messias: Notas sobre o surto sócio-religioso do Catulé. In: PEREIRA, João Baptista Borges; QUEIROZ, Renato Silva. (Org.). Messianismo e milenarismo no Brasil. São Paulo: Edusp, 2015.

REGO, José Lins do. Pedra Bonita. Rio de Janeiro: José Olímpio Editora, 1973.

ROCHA, Glauber. Direção e roteiro dos filmes "Deus e o diabo na terra do sol" (1963) e "O dragão da maldade contra o santo guerreiro" (1969).

SILVA, Severino Vicente da (Org.). A Igreja e o controle social nos sertões nordestinos. São Paulo: Paulinas, 1988.

SOUZA NETO, Francisco Benjamin. Antonio Conselheiro e Canudos; livro de Ataliba Nogueira Simpósio, n.13, p. 36-37, 1995.

VASCONCELlOS, Pedro Lima. Do Belo Monte das promessas a Canudos destruída: O drama bíblico na Jerusalém do sertão, Maceió, Editora Catavento, 2010.

VASCONCELLOS, Pedro Lima. Messianismos: Problemas de um conceito. In: Conferência, $3^{\circ}$ Congresso Nacional ANPTECRE, 2011, São Paulo, CD, Anais.

VILLA, Marco Antonio. Canudos. O povo da terra. São Paulo: Ática, 1995.

WATTS, Martha. Cartas de Martha Watts, 1881-1908. In: MESQUITA, Zuleica (Org.) Evangelizar e Civilizar. Piracicaba: Editora Unimep, 2001.

Submetido em: 2-7-2016

Aceito em: 16-04-2017 